\title{
Analisis Kemampuan Pemecahan Masalah IPA Siswa Kelas VII pada Konsep Pencemaran Lingkungan di MTs. Asnawiyah Kab. Bogor
}

\author{
Oktaviana Rahayu $^{1 *}$, Martua Ferry Siburian $^{1}$, Andri Suryana ${ }^{2}$
}

$I^{2}$ Fakultas MIPA, Prodi Pendidikan Biologi, Universitas Indraprasta PGRI

${ }^{2}$ Fakultas Pascasarjana, Prodi Pendidikan MIPA,Universitas Indraprasta PGRI

*email: oktavianarahayu97@gmail.com

\begin{tabular}{l} 
Article History \\
\hline Received: \\
$25 / 09 / 2020$ \\
Revised: \\
$1 / 10 / 2020$ \\
Accepted: \\
10/11/2020 \\
Kata kunci: \\
Kemampuan \\
pemecahan \\
masalah \\
Pencemaran \\
lingkungan \\
\\
Keywords: \\
Problem solving \\
skill \\
Environmental \\
pollution
\end{tabular}

\begin{abstract}
ABSTRAK
Tujuan penelitian ini adalah untuk menganalisis kemampuan pemecahan masalah IPA Siswa Kelas VII Pada Konsep Pencemaran Lingkungan di MTs Asnawiyah Kab. Bogor. Metode penelitian yang digunakan adalah deskriptif kualitatif. Dalam penelitian ini, menggunakan subjek sebanyak 20 siswa. Teknik sampling yang digunakan adalah purposive sampling. Hasil penelitian menunjukkan bahwa kemampuan pemecahan masalah IPA siswa kelas VII di MTs Asnawiyah Kab. Bogor masih tergolong rendah. Hal ini dapat dilihat dari perolehan hasil penelitian sebagai berikut: tahap memahami masalah sebesar $(15,4 \%)$, tahap merencanakan strategi sebesar $(21,1 \%)$, tahap melaksanakan strategi sebesar $(18,7 \%)$, dan tahap memeriksa kembali kebenaran solusi sebesar $(5,6 \%)$. Berdasarkan hasil rata-rata pencapaian skor keempat tahapan tersebut, maka ratarata skor terendah kemampuan pemecahan masalah IPA siswa terdapat pada tahap memeriksa kembali kebenaran solusi.
\end{abstract}

ABSTRACT
The purpose of this thesis research or final project is to analyze the Science Problem Solving
Ability of Class VII Students on the Concept of Environmental Pollution at MTs Asnawiyah Kab.
Bogor. The research method used is descriptive qualitative. In this study, using a subject as many
as 20 students. Thechnique sampling used was purposive sampling. The results showed that the
seventh grade students' science problem solving skills at MTs Asnawiyah Kab. Bogor is still
relatively low. This can be seen from the acquisition of research results as follows: the stage of
understanding the problem (15.4\%), the stage of planning the strategy (21.1\%), the stage of
implementing the strategy (18.7\%), and the stage of checking the correctness of the solution.
amounting to (5.6\%). Based on the results of the average score achievement of the four stages, the
lowest average score of students' science problem solving abilities is at the stage of re-checking
the correctness of the solution.

Copyright (C) 2021 LPPM Universitas Indraprasta PGRI. All Right Reserved

\section{PENDAHULUAN}

Pendidikan merupakan hal yang penting dalam kehidupan manusia, karena dengan pendidikan kita dapat belajar mengenai ilmu pengetahuan, dan dengan pendidikan juga dapat merubah polapikir manusia menjadi lebih baik. Jadi setiap manusia khususnya masyarakat Indonesia berhak mendapatkan pendidikan dan diharapkan untuk selalu berkembang di dalamnya, karena kemajuan suatu negara dapat diukur atau dapat dilihat dari kemajuan pendidikan masyarakatnya. Pendidikan secara umum mempunyai arti suatu proses kehidupan dalam mengembangkan diri untuk dapat hidup dan melangsungkan kehidupannya pada yang lebih baik. Kita dididik menjadi orang yang berguna baik bagi negara, Nusa dan Bangsa. Pendidikan bisa didapat dari pendidikan nonformal (Lingkungan masyarakat), pendidikan informal (Lingkungan keluarga) dan formal (Lingkungan Sekolah). 
Di dalam pendidikan pembelajaran formal (Lingkungan sekolah) salah satu mata pelajaran yang sangat penting adalah Ilmu Pengetahuan Alam (IPA). Ilmu Pengetahuan Alam (IPA) merupakan ilmu yang mempelajari segala sesuatu tentang fenomena-fenomena di alam semesta. Ilmu Pengetahuan Alam (IPA) berkaitan dengan cara mencari tahu tentang alam secara sistematis, sehingga IPA bukan hanya penguasaan kumpulan pengetahuan yang berupa fakta-fakta, konsepkonsep, atau prinsip-prinsip saja tetapi juga merupakan suatu proses penemuan. Pada hakekatnya IPA dapat dipandang dari segi produk, proses, dan dari segi pengembangan sikap. Proses pembelajarannya menekankan pada pemberian pengalaman langsung untuk mengembangkan kompetensi agar menjelajahi dan memahami alam sekitar secara ilmiah.

Dalam pelajaran IPA dipelajari berbagai konsep, salah satunya adalah materi Pencemaran lingkungan. Pencemaran lingkungan erat kaitannya dengan fenomena dan gejala alam yang dapat terjadi oleh beberapa faktor. Materi Pencemaran Lingkungan terdapat di dalam kurikulum 2013 KD 3.8 kelas VII semester 2. Hal yang berkaitan dengan pencemaran lingkungan dapat dengan mudah dijumpai pada lingkungan sekitar peserta didik. Misalnya pembuangan limbah industri, limbah rumah tangga dan limbah pertanian ke sungai serta banyaknya asap yang dihasilkan oleh kendaraan bermotor dan lain sebagainya. Pada KI dan KD tersebut, siswa diharapkan mampu memahami pencemaran dan dampaknya bagi makhluk hidup. Untuk mencapai KD dalam pembelajaran konsep pencemaran lingkungan diperlukan kemampuan siswa dalam mencari informasi, mengolah informasi, mengambil keputusan dan memecahkan masalah. Permasalahan lingkungan terus terjadi pada berbagai tempat dimuka bumi seperti peningkatan pembangunan pabrik atau industri-industri yang menjadi masalah serius, karena menyebabkan pencemaran yang terus meningkat dari waktu ke waktu. Penyebab pencemaran lingkungan ini adalah manusia yang melakukan berbagai kegiatan untuk memenuhi kebutuhan hidup tersebut, yang pada akhirnya akan menghasilkan sisa berupa sampah atau limbah yang dibuang ke lingkungan.

Pembelajaran pada konsep pencemaran lingkungan ini membutuhkan beragam kemampuan IPA, salah satunya adalah kemampuan pemecahan masalah. Kemampuan pemecahan masalah IPA adalah suatu proses penghilangan perbedaan atau ketidaksesuaian yang terjadi antara hasil yang diperoleh dan hasil yang diinginkan. Salah satu bagian dari proses pemecahan masalah adalah pengambilan keputusan yang didefinisikan sebagai solusi terbaik dari sejumlah alternatif yang tersedia. Pengambilan keputusan yang tidak tepat, akan mempengaruhi kualitas hasil dari pemecahan masalah yang dilakukan. Namun kemampuan pemecahan masalah IPA pada siswa ternyata masih rendah, hal ini terlihat dari kemampuan mereka yang mengalami kesulitan pada saat mempelajari materi pencemaran lingkungan. Hal ini disebabkan karena guru masih menggunakan metode pembelajaran konvensional, dan siswa pun kurang dihadapkan dengan masalah-masalah konkret, karena masalah yang diberikan siswa tidak kompleks, monoton, dan kurang bervariasi. Selain itu salah satu faktor yang mempengaruhi rendahnya hasil pencapaian pemecahan masalah IPA pada siswa juga berasal dari dalam diri siswa sendiri, yang merasa sukar mencerna pelajaran IPA karena materinya dianggap sulit dan harus banyak menghafal.

Salah satu indikasi bahwa kemampuan pemecahan masalah IPA siswa tergolong rendah, diperkuat juga dengan hasil observasi pada salah satu sekolah swasta di daerah Kendari melalui studi pendahuluan yang dilakukan pada siswa kelas VIII yang berjumlah 135 orang. Soal kemampuan pemecahan masalah dalam bentuk essay yang diujikan pada siswa kelas VIII, yang telah menerima materi Ekosistem dengan model pembelajaran konvensional. Materi tersebut di antaranya Interaksi Makhluk Hidup dengan Lingkungannya, Pencemaran Lingkungan dan Pemanasan Global. Studi pendahuluan tersebut memberikan hasil bahwa kemampuan pemecahan masalah siswa masih tergolong rendah dengan skor rata-rata 48, 18 .

Melihat permasalahan tersebut, sudah seharusnya seorang guru sejak dini melatihkan siswa pada kemampuan pemecahan masalah IPA. Hal ini dapat dilakukan dengan cara menghadirkan masalah yang dapat melatih dan mengembangkan kemampuan pemecahan maslah IPA siswa dalam proses pembelajaran. Pemecahan masalah yang digunakan dalam pembelajaran juga dapat membuat siswa mengkontruksi pengetahuannya dan mengambil peran dalam perolehan pengetahuan. Berdasarkan uraian diatas peneliti akan mencoba melihat 
sejauh mana kemampuan pemecahan masalah IPA siswa pada konsep Pencemaran lingkungan.

\section{METODE PENELITIAN}

Penelitian ini dilaksanakan di MTs. Asnawiyah kab. Bogor pada semester genap tahun pelajaran 2019/2020. Metode yang digunakan dalam penelitian ini adalah metode deskriptif kualitatif. Adapun Subjek dalam penelitian ini adalah siswa kelas VII di MTs. Asnawiyah Kab.Bogor, dengan kelas yang diambil sebagai subjek penelitian adalah kelas VII sebanyak 20 siswa. Untuk teknik samplingnya, peneliti menggunakan Purposive Sampling dan sumber datanya berasal dari siswa sebagai subjek penelitian.

Tabel 1. Indikator pemecahan masalah menurut Polya

\begin{tabular}{|c|c|}
\hline Indikator & Keterangan \\
\hline Pemahaman Masalah & $\begin{array}{l}\text { Subjek mampu memahami } \\
\text { apa yang diketahui dan } \\
\text { ditanyakan pada soal yang } \\
\text { diberikan. }\end{array}$ \\
\hline Perencanaan Strategi & $\begin{array}{l}\text { Subjek mampu menentukan } \\
\text { rumus/cara/metode yang } \\
\text { bisa digunakan untuk } \\
\text { menyelesaikan soal yang } \\
\text { diberikan. }\end{array}$ \\
\hline Pelaksanaan Strategi & $\begin{array}{l}\text { Subjek mampu menentukan } \\
\text { rumus/cara/metode yang } \\
\text { telah direncanakan untuk } \\
\text { menyelesaikan soal yang } \\
\text { diberikan. }\end{array}$ \\
\hline Pengecekan Kembali & $\begin{array}{l}\text { Subjek mengoreksi kembali } \\
\text { jawaban yang telah } \\
\text { diberikan dalam } \\
\text { menyelesaikan soal untuk } \\
\text { memastikan jawaban. }\end{array}$ \\
\hline
\end{tabular}

Penelitian ini menggunakan beragam instrumen, yaitu dokumen (hasil tes kemampuan pemecahan masalah IPA siswa), lembar observasi, pedoman wawancara, dan peneliti. Tes kemampuan pemecahan masalah yang digunakan dalam penelitian ini sudah divalidasi sehingga siap untuk digunakan dalam penelitian. Adapun metode pengumpulan data yang digunakan adalah metode triangulasi, sedangkan teknik analisis datanya menggunakan Model Miles dan Huberman. Aktivitas analisis data dalam model tersebut meliputi reduksi data, penyajian data, dan penarikan kesimpulan (Sugiyono, 2011). Untuk uji keabsahan datanya, peneliti menggunakan uji kredibilitas (melalui triangulasi).

\section{HASIL DAN PEMBAHASAN}

Kemampuan pemecahan masalah IPA pada siswa yang akan dikaji dalam penelitian ini meliputi aspek memahami masalah, merencanakan strategi, melaksanakan strategi, serta memeriksa kembali kebenaran solusi. Adapun daftar nama subjek penelitian yang diperoleh sebagaimana tercantum dalam Tabel 2.

Tabel 2. Daftar nama subjek penelitian

\begin{tabular}{cc}
\hline NO. & KODE SUBJEK \\
\hline 1 & AR \\
2 & AN \\
3 & AD \\
4 & AZ \\
5 & DS \\
6 & GS \\
7 & GP \\
8 & HP \\
9 & LA \\
10 & MP \\
11 & MH \\
12 & MI \\
13 & MJ \\
14 & MA \\
15 & MD \\
16 & NA \\
17 & SA \\
18 & SS \\
19 & SAP \\
20 & ZB \\
\hline
\end{tabular}

Subjek penelitian yang telah terpilih kemudian diminta untuk mengerjakan soal tes tertulis untuk mengetahui kemampuan pemecahan masalah IPA siswa. Kemudian setelah tes tertulis dilaksanakan, dilanjutkan dengan tes wawancara. Hasil pengerjaan tes tertulis dan hasil wawancara siswa akan menjadi data untuk dianalisis pada bab ini. Data tersebut kemudian diuraikan menurut langkah pemecahan masalah polya yang meliputi memahami masalah, merencanakan strategi, melaksanakan strategi, dan memeriksa kembali kebenaran solusi. Kemampuan pemecahan masalah dilakukan berdasarkan langkah-langkah penyelesaian soal. Selanjutnya data dianalisis berdasarkan nilai rataan indikator pemecahan masalah. Adapun hasilnya disajikan pada Tabel 3. 
Berdasarkan Tabel 3, terlihat bahwa persentase total dari skor pada keempat indikator memiliki perbedaan antara satu dengan yang lain. Pada Tabel 3 tertera bahwa persentase total pada indikator 1 yaitu $(15,4 \%)$, persentase total pada indikator 2 yaitu $(21,1 \%)$, persentase total pada indikator 3 yaitu $(18,7 \%)$, sedangkan persentase total pada indikator 4 yaitu $(5,6 \%)$. Hal ini menunjukkan bahwa kemampuan pemecahan masalah IPA siswa pada indikator 2 lebih tinggi dibandingkan kemampuan pemecahan masalah IPA siswa pada ketiga indikator lainya. Sedangkan kemampuan pemecahan masalah IPA siswa pada indikator 4 lebih rendah dibandingkan kemampuan pemecahan masalah IPA siswa pada ketiga indikator yang lain. Apabila hal ini terjadi, maka dapat diketahui bahwa rendahnya kemampuan pemecahan masalah IPA siswa kelas VII pada konsep pencemaran lingkungan di MTs. Asnawiyah Kab. Bogor lebih banyak terjadi pada indikator 4.

Tabel 3. Deskripsi data indikator pemecahan masalah

\begin{tabular}{|c|c|c|c|c|c|c|}
\hline No. & Kode Subjek & $\begin{array}{c}\text { Rataan } \\
\text { Indikator 1 }\end{array}$ & \begin{tabular}{|c|} 
Rataan \\
Indikator 2 \\
\end{tabular} & \begin{tabular}{|c|} 
Rataan \\
Indikator 3 \\
\end{tabular} & \begin{tabular}{|c|} 
Rataan \\
Indikator 4 \\
\end{tabular} & Total \\
\hline 1 & AR & 1 & 1,6 & 1,4 & 0,6 & 4,6 \\
\hline 2 & $\mathrm{AN}$ & 2 & 2,6 & 3,8 & 1 & 9,4 \\
\hline 3 & $\mathrm{AD}$ & 2 & 2 & 0,8 & 0,4 & 5,2 \\
\hline 4 & $\mathrm{AZ}$ & 1,6 & 2,2 & 0,4 & 0,4 & 4,6 \\
\hline 5 & DS & 1,6 & 2 & 2 & 0,6 & 6,2 \\
\hline 6 & GS & 1,6 & 2 & 2,8 & 0,4 & 6,8 \\
\hline 7 & GP & 1,2 & 2,4 & 1,4 & 0,8 & 5,8 \\
\hline 8 & HP & 1,4 & 2,2 & 0,6 & 0,6 & 4,8 \\
\hline 9 & LA & 1,2 & 2,2 & 3,4 & 0,4 & 7,2 \\
\hline 10 & MP & 1,6 & 1,6 & 1,8 & 0,4 & 5,4 \\
\hline 11 & MH & 1,2 & 1,8 & 2 & 0,6 & 5,6 \\
\hline 12 & MI & 1,4 & 2,2 & 1,2 & 0,4 & 5,2 \\
\hline 13 & MJ & 1,6 & 2,2 & 2,4 & 0,4 & 6,6 \\
\hline 14 & MA & 1,8 & 1,8 & 2,2 & 0,2 & 6 \\
\hline 15 & MD & 1,8 & 1,8 & 1,6 & 0,6 & 5,8 \\
\hline 16 & NA & 1,6 & 2,6 & 0,4 & 0,6 & 5,4 \\
\hline 17 & SA & 1,2 & 1,8 & 1,8 & 0,6 & 5,4 \\
\hline 18 & SS & 1,6 & 2,6 & 2 & 0,4 & 6,6 \\
\hline 19 & SAP & 1,6 & 2,2 & 2 & 0,8 & 6,6 \\
\hline 20 & ZB & 1,8 & 2,4 & 3,4 & 0,8 & 8,4 \\
\hline \multicolumn{2}{|c|}{ Rataan Total } & 1,54 & 2,11 & 1,87 & 0,56 & 6,08 \\
\hline \multicolumn{2}{|c|}{ Total All } & 30,8 & 42,2 & 37,4 & 11,2 & 121,6 \\
\hline \multicolumn{2}{|c|}{$\%$ Total } & $15,40 \%$ & $21,10 \%$ & $18,70 \%$ & $5,60 \%$ & $60,80 \%$ \\
\hline \multicolumn{2}{|c|}{ n Total } & 20 & 20 & 20 & 20 & 20 \\
\hline
\end{tabular}

\section{Keterangan Indikator:}

(1) Memahami masalah

(2) Merencanakan strategi

(3) Melaksanakan strategi

(4) Memeriksa kembali kebenaran solusi

Berdasarkan hasil analisis data, diperoleh temuan bahwa kemampuan pemecahan masalah IPA siswa dapat dinilai dari kemampuan rata-rata siswa dalam menjawab soal pada setiap indikatornya. Secara keseluruhan hasil kemampuan pemecahan masalah IPA siswa pada 
persentase total indikator 'memeriksa kebenaran solusi' masih terlihat rendah. Sementara itu hasil kemampuan pemecahan masalah IPA siswa pada persentase total indikator 'merencanakan strategi' terlihat lebih tinggi. Lain halnya dengan persentase total hasil kemampuan pemecahan masalah IPA siswa pada indikator 'melaksanakan strategi' dan 'memahami masalah'.

Untuk memperkuat hasil analisis deskriptif tersebut, maka analisis dilanjutkan pada jawaban siswa. Jawaban siswa akan dianalisis agar diperoleh hasil yang lebih mendalam terkait kemampuan pemecahan masalah IPA siswa dalam menyelesaikan soal pencemaran lingkungan. Adapun ringkasan hasil penelitian jawaban berdasarkan indikator kemampuan pemecahan masalah IPA siswa adalah sebagai berikut:

\section{Indikator Tahap Memahami Masalah}

Pada bagian ini adalah pemaparan data hasil tes dan wawancara subjek inisial MJR dan LA dalam memecahkan masalah. Pada tahap memahami masalah ini, kemampuan pemecahan masalah yang akan diungkap ialah menyatakan soal dengan bahasa sendiri, siswa dapat memahami apa yang diketahui dari soal dan menuliskan kembali hal apa yg ditanyakan dari soal. Berikut adalah jawaban siswa MJR pada tahap memahami masalah yang mampu mengidentifikasi masalah dengan baik:

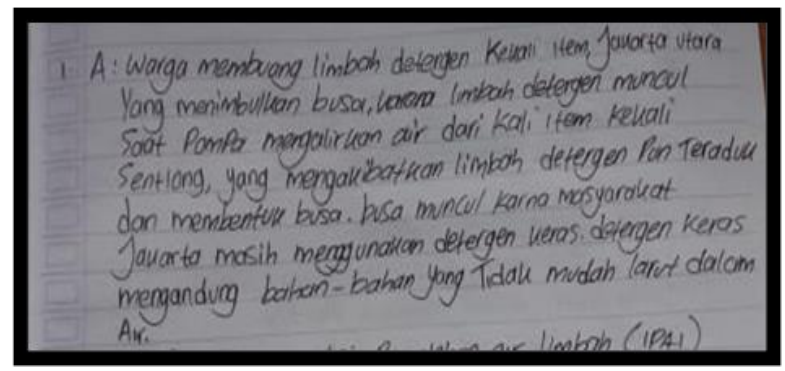

Gambar 1. Jawaban siswa MJR

Gambar tersebut menunjukkan bahwa jawaban siswa MJR mampu mengidentifikasi masalah sesuai dengan permasalahan yang disajikan dalam pertanyaan penelitian. Siswa MJR mampu mengidentifikasi pencemaran air yang berasal dari limbah detergen yang berada pada salah satu kali di daerah Jakarta.

Sebagai pembanding berikut disajikan gambar contoh jawaban siswa LA pada tahap memahami masalah yang masih belum mampu mengidentifikasi masalah dengan baik:

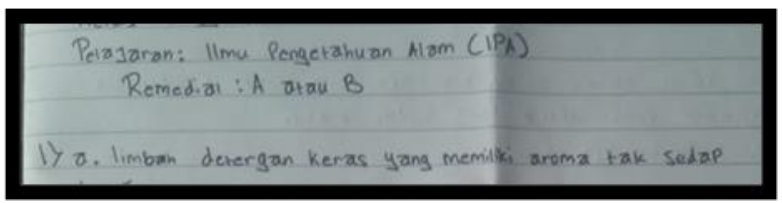

Gambar 2. Jawaban siswa LA

Terlihat gambar tersebut menunjukkan bahwa jawaban siswa LA belum mampu mengidentifikasi masalah sesuai dengan pertanyaan yang diberikan. Siswa LA tidak dapat menjelaskan permasalahan apa yang sedang terjadi pada peristiwa pencemaran air yang disebabkan limbah detergen. Temuan ini diperkuat oleh hasil wawancara pada perwakilan siswa yang telah mengerjakan soal pada indikator 1. Bahwa mereka mengakui dapat mengerjakan soal terkait kemampuan mereka dalam memahami masalah yang diberikan, sebelum membuat perencanaan selanjutnya namun mereka juga mengakui bahwa kadangkala mereka cenderung lama dalam memahami masalah tersebut.

\section{Tahap Merencanakan Strategi}

Pada bagian ini adalah pemaparan data hasil tes dan wawancara subjek inisial HP dan MP dalam memecahkan masalah. Pada tahap merencanakan strategi ini, kemampuan pemecahan masalah yang akan diungkap ialah siswa dapat membuat rencana langkah-langkah penyelesaian dari soal yang diberikan. Berikut adalah jawaban siswa HP pada tahap merencanakan strategi:

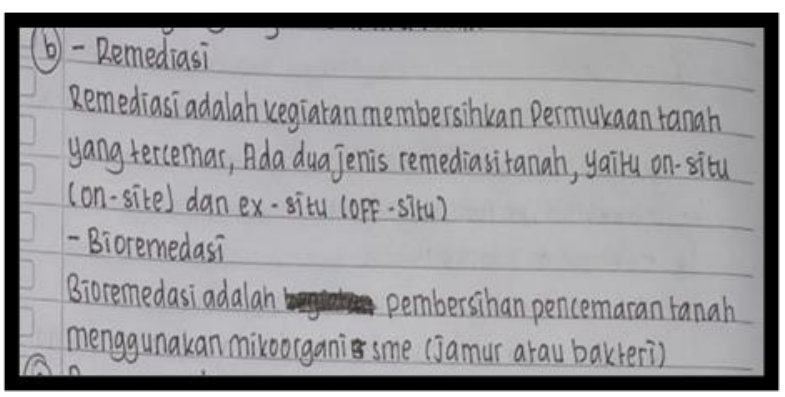

Gambar 3. Jawaban siswa HP

Gambar tersebut menunjukkan bahwa jawaban siswa HP sudah mampu merencanakan dengan baik soal pemecahan masalah yang diberikan dengan tepat dan benar sesuai yang disajikan dalam pertanyaan penelitian. Siswa HP mampu membuat alternatif solusi dengan memberikan perencanaan strategi untuk mengurangi terjadinya permasalahan pencemaran tanah yang terjadi.

Sebagai pembanding berikut disajikan gambar contoh jawaban siswa MP yang masih belum mampu merencanakan pemecahan masalah dengan baik: 
B. - Menanam tanaman / Penghijavan.

- Stor membuang sampah sembarangan.

Gambar 4. Jawaban siswa MP

Gambar tersebut menunjukkan bahwa jawaban siswa MP belum mampu merencanakan dengan baik soal pemecahan masalah yang diberikan dengan tepat dan benar sesuai yang disajikan dalam pertanyaan penelitian, ia juga belum mampu membuat alternatif solusi dalam memberikan perencanaan strategi untuk mengurangi terjadinya permasalahan pencemaran tanah yang diberikan. Temuan ini juga diperkuat oleh hasil wawancara pada perwakilan siswa yang telah mengerjakan soal pada indikator 2. Bahwa mereka mengakui dapat memberikan strategi berupa alternatif solusi dalam menyelesaikan permasalahan yang terjadi, hanya saja mereka masih kurang teliti dalam pengerjaannya sehingga jawaban yang diberikan terlihat belum maksimal.

\section{Tahap Melaksanakan Strategi}

Pada bagian ini adalah pemaparan data hasil tes dan wawancara subjek inisial SS dan GST dalam memecahkan masalah. Pada tahap melaksanakan strategi ini, kemampuan pemecahan masalah yang akan diungkap ialah siswa dapat menjelaskan langkah-langkah penyelesaian dari soal yang diberikan. Berikut adalah jawaban siswa SS pada tahap melaksanakan strategi:

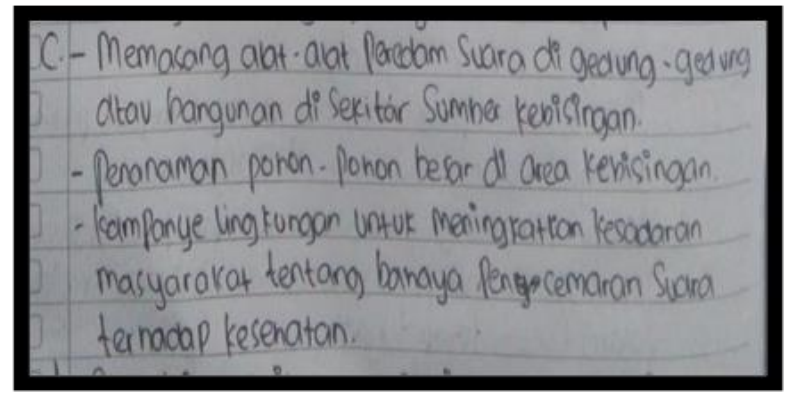

Gambar 5. Jawaban siswa SS

Gambar tersebut menunjukkan bahwa jawaban siswa SS sudah mampu menyebutkan dan menjelaskan langkah-langkah penyelesaian pemecahan masalah dengan benar sesuai pertanyaan yang disajikan dalam penelitian. Namun siswa SS masih kurang teliti dalam menyelesaikan pertanyaan yang diberikan. Siswa SS seharusnya hanya menjelaskan satu langkah solusi saja terhadap permasalahan pencemaran suara yang terjadi.
Sebagai pembanding berikut disajikan gambar contoh jawaban siswa GST pada tahap melaksanakan strategi yang masih belum mampu menjelaskan permasalahan dengan baik:

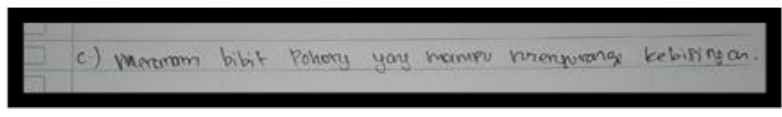

Gambar 6. Jawaban siswa GST

Gambar tersebut menunjukkan bahwa jawaban siswa GST belum mampu menyebutkan dan menjelaskan langkah-langkah penyelesaian pemecahan masalah dengan benar sesuai pertanyaan yang disajikan dalam penelitian. Jawaban tersebut juga kurang lengkap dan siswa kurang dapat memilih solusi yang tepat dalam menyelesaikan permasalahan pencemaran suara yang terjadi. Temuan ini diperkuat oleh hasil wawancara pada perwakilan siswa yang telah mengerjakan soal pada indikator 3. Mereka mengakui bahwa mampu memberikan langkahlangkah penyelesaian alternatif solusi pada permasalahan tersebut, namun masih bingung dalam menuliskannya.

\section{Tahap Memeriksa Kembali Kebenaran Solusi}

Pada bagian ini adalah pemaparan data hasil tes dan wawancara subjek inisial AN dan GP dalam memecahkan masalah. Pada tahap memeriksa kembali kebenaran solusi ini, kemampuan pemecahan masalah yang akan diungkap ialah siswa dapat membuat kesimpulan dari apa yang telah ia kerjakan dan siswa meyakini kebenaran dari jawaban yang telah dibuat dengan diperkuat oleh hasil teori yang sesuai. Berikut adalah jawaban siswa AN pada tahap memeriksa kembali kebenaran solusi:

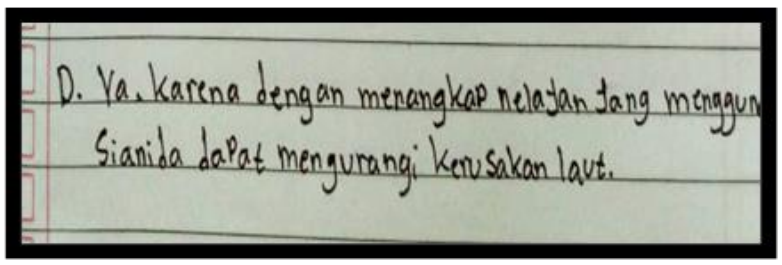

Gambar 7. Jawaban siswa AN

Gambar tersebut menunjukkan bahwa jawaban siswa AN masih mengalami kesulitan dalam menjawab pertanyaan dengan benar sesuai pertanyaan yang disajikan dalam penelitian. Hal ini terlihat dari pemberian jawaban yang kurang tepat.

Sebagai pembanding berikut disajikan gambar contoh jawaban siswa GP pada tahap memeriksa 
kembali kebenaran solusi yang juga belum mampu memberikan kesimpulan terhadap permasalahan dengan baik:

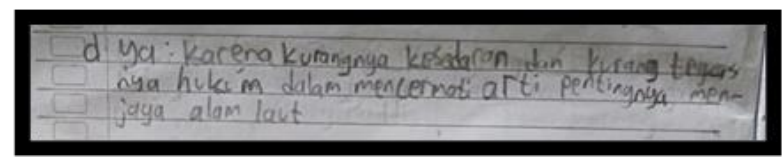

Gambar 8. Jawaban siswa GP

Gambar tersebut menunjukkan bahwa jawaban siswa GP juga belum mampu membuat kesimpulan dari apa yang telah ia kerjakan, dan ia juga belum meyakini sepenuhnya dari jawaban yang telah dibuat serta jawaban juga tidak diperkuat oleh hasil teori sehingga jawaban yang diberikan masih kurang tepat dan tidak sesuai dengan pertanyaan yang diberikan. Temuan ini diperkuat oleh hasil wawancara pada perwakilan siswa yang telah mengerjakan soal pada indikator 4. Bahwa mereka telah memeriksa kembali kebenaran solusi pada jawaban sebelumnya, namun mereka masih belum memahami maksud dari soal yang diberikan terkait jawaban yang harus diperkuat dengan hasil teori yang sesuai.

Berdasarkan uraian di atas, maka diperoleh kesimpulan bahwa secara keseluruhan siswa kelas VII MTs. Asnawiyah Kab. Bogor masih rendah dalam menyelesaikan soal kemampuan pemecahan masalah yang diberikan. Meskipun demikian terlihat dari persentase total indikator 2 yaitu 'merencanakan strategi' terlihat lebih tinggi, namun persentase total pada indikator 4 yaitu 'memeriksa kembali kebenaran solusi' masih terlihat rendah dibandingkan dengan ketiga indikator lainya. Indikator kemampuan pemecahan masalah siswa di atas, idealisnya sudah mampu melewati semua indikator meskipun ada tahapan yang belum maksimal mereka lalui mulai dari memahami masalah, merencanakan strategi, melaksanakan strategi, dan memeriksa kembali kebenaran solusi. Kurangnya kemampuan pemecahan masalah IPA siswa tersebut bisa disebabkan karena siswa belum memahami masalah dengan baik, tidak dapat membuat rencana/strategi penyelesaian masalah dengan tepat, dan kesulitan dalam melaksanakan rencana pemecahan masalah yang mengakibatkan siswa salah dalam menjawab permasalahan.

Rendahnya kemampuan pemecahan masalah IPA siswa tersebut juga disebabkan karena pembelajaran yang biasa diperoleh siswa di sekolah masih menggunakan metode pembelajaran konvensional sehingga siswa kurang dihadapkan dengan masalah-masalah konkret, karena masalah yang diberikan siswa tidak kompleks, monoton, dan kurang bervariasi. Diketahui bahwa masalah terbesar siswa dalam pembelajaran terletak pada kemampuan mereka dalam memecahkan masalah, dimana ketika diberikan soal sebagian besar siswa masih bingung untuk menuliskan langkah-langkah penyelesaiannya. Ada beberapa faktor penyebab rendahnya siswa dalam menyelesaikan masalah yaitu; a) kurangnya pemahaman siswa terhadap masalah yang diberikan; b) kurangnya kemandirian siswa dalam melakukan perencanaan dalam pemecahanan masalah; c) dan penguasaan siswa dalam membaca soal yang masih rendah. Maka hendaknya pembelajaran yang harus diperoleh siswa tidak terlepas dari pembelajaran pemecahan masalah, karena pemecahan masalah merupakan tahapan dalam teori belajar yang paling tinggi sehingga hal itu akan terus meningkatkan kemampuan siswa dalam memecahkan setiap permasalahan yang diberikan.

Hasil penelitian yang diperoleh ini hampir sejalan dengan hasil penelitian terdahulu yang dilakukan oleh Siti Syahrotun (2016) dalam skripsinya yang berjudul "Analisis Kemampuan Pemecahan Masalah Matematis Siswa SMP Kelas VII Di Kota Bandung" yang menjelaskan bahwa masih rendahnya tingkat kemampuan pemecahan masalah siswa, yang mengakibatkan mereka tidak mampu membuat perencanaan penyelesaian masalah yang diberikan.

Berdasarkan penelitian yang telah dilakukan maka kesimpulan yang diperoleh adalah kemampuan pemecahan masalah diperlukan untuk melatih siswa agar terbiasa menghadapi berbagai permasalahan dalam kehidupannya yang semakin kompleks, bukan hanya pada masalah IPA itu sendiri tetapi juga masalah-masalah dalam bidang studi lain dan masalah dalam kehidupan seharihari. Oleh karena itu, kemampuan siswa untuk memecahkan masalah perlu terus dilatih sehingga siswa tersebut mampu menyelesaikan berbagai permasalahan yang dihadapinya. Kemampuan pemecahan masalah ini dapat membantu siswa membuat keputusan yang tepat, cermat, sistematis, logis, dan mempertimbangkan berbagai sudut pandang. Sebaliknya, kurangnya kemampuan pemecahan masalah dapat mengakibatkan siswa terbiasa melakukan berbagai kegiatan tanpa mengetahui tujuan dan alasan yang dilakukannya.

\section{KESIMPULAN}

Analisis kemampuan pemecahan masalah IPA siswa kelas VII pada konsep pencemaran 
lingkungan semester genap tahun ajaran 2019/2020 memiliki rerata persentase kemampuan pemecahan masalah dengan kriteria rendah pada indikator 4 yakni pada aspek 'memeriksa kembali kebenaran solusi'. Kurangnya kemampuan pemecahan masalah IPA siswa bisa disebabkan karena siswa belum memahami masalah dengan baik, tidak dapat membuat rencana/strategi penyelesaian masalah dengan tepat, dan kesulitan dalam melaksanakan rencana pemecahan masalah yang mengakibatkan siswa kurang tepat atau salah dalam menjawab permasalahan. Hambatan tersebut muncul dikarenakan beberapa faktor, diantaranya adalah kurangnya pemahaman siswa terhadap pengetahuan atau materi yang berkaitan dengan masalah yang diahadapi, kurangnya latihan dalam memecahkan masalah, dan kurangnya ketertarikan siswa terhadap pembelajaran IPA. Berdasarkan simpulan yang telah dirumuskan, maka peneliti mengajukan saran pada peneliti selanjutnya yang akan menganalisis kemampuan siswa direkomendasikan untuk menganalisis kemampuan IPA lainya, dan sebaiknya meneliti variabel lain yang dianggap dapat mempengaruhi kemampuan pemecahan masalah IPA siswa, sehingga dapat memberikan manfaat yang lebih luas untuk bidang pendidikan Ilmu Pengetahuan Alam.

\section{UCAPAN TERIMA KASIH}

1. DR. KH. Agus Setiawan, Lc., MA selaku pimpinan Yayasan Kursiya Kab. Bogor.

2. Hj. Siti Hafidah Ayub Asnawi, Lc., MA selaku Kepala Madrasah Tsanawiyah Asnawiyah Kab.Bogor.

3. Iman Jatnika selaku guru Ilmu Pengetahuan Alam (IPA) di Madrasah Tsanawiyah Asnawiyah Kab. Bogor

\section{DAFTAR PUSTAKA}

Arikunto, S. (2012). Dasar-dasar Evaluasi Pendidikan. Bumi Aksara: Jakarta.

------- (2012). Metode Penelitian Kuantitatif

Kualitatif dan $R \& D$. Alfabeta: Bandung.

----- (2013). Metode Penelitian Kuantitatif

Kualitatif dan $R \& D$. Bandung: Alfabeta.

------ (2015). Metode Penelitian Kombinasi (Mix

Methods). Alfabeta: Bandung.

------- (2016). Metode Penelitian Kuantitatif

Kualitatif dan $R \& D$. Bandung: Alfabeta.

------- (2017). Metode Penelitian Kuantitatif

Kualitatif dan $R \& D$. Bandung: Alfabeta.
-Arti kata - Kamus Besar Bahasa Indonesia (KBBI). [Online]. Diakses pada 22 Juni 2020, dari https://www.kbbi.web.id/.

Ayu, T. A. (2014). Konsep Dasar IPA: Aspek Biologi. Penerbit Ombak: Yogyakarta.

Daraji, H., \& Probosari, R. M. (2014). Ilmu Pengetahuan Alam. PT Tiga Serangkai Pustaka Mandiri: Solo.

Djojosoediro. (2012). Hakikat IPA dan Pembelajaran IPA. [Online]. Diakses pada 27 juni 2020, dari http://tpardede.wikispaces.com/file/view/ipa_u nit_1.pdf.

Emzir. (2011). Metodologi Penelitian Kualitatif Analisis Data. Rajawali Pers: Jakarta.

Ilmiyana, M. (2018). Analisis Kemampuan Pemecahan Masalah Matematis Siswa SMA Ditinjau Dari Tipe Kepribadian Dimensi MyerBriggs Type Indicator (MBTI) Lampung. Skripsi (UIN Raden Intan Lampung).

Indarwati, D. (2014). Peningkatan Kemampuan Pemecahan Masalah Matematika Melalui Penerapan Problem Based Learning Untuk Siswa Kelas V SD. Tersedia: http://ris.uksw.edu/download/jurnal/kode/J011 67.

Lestanti, M. M. (2015). Analisis Kemampuan Pemecahan Masalah Ditinjau Dari Karakteristik Cara Berpikir Siswa Dalam Model Problem Based Learning. Semarang. Skripsi (UNS).

Mahira. (2012). Penerapan Model Project Based Learning Untuk Meningkatkan Kemampuan Memecahkan Masalah Siswa pada Konsep Pencemaran Lingkungan. Bandung. Skripsi (UPI).

Marlina, L. (2013). Penerapan langkah polya dalam menyelesaikan soal cerita keliling dan luas persegi panjang. Ilmiah, 11 (53), 1-11. http://jurnal.untad.ac.id/jurnal/index.php/JEPM T/article/download/1708/1125.pdf.

Miles, M. B., Huberman, A. M., \& Saldana, J. (2011). Qualitative Data Analysis, A Methods Sourcebook, Edition 3. USA: Sage Publications. Terjemahan Tjetjep Rohindi Rohidi. UI-Press: Jakarta.

Mundilarto, dkk. (2011). IPA Terpadu 1. Perpustakaan Nasional. Katalog Dalam Terbitan (KDT). Jakarta.

Novan. A. (2011). Jurnal Pencemaran Air. [Online]. Diakses pada 03 Juli 2020, dari https: //www. academia.edu /5350480/ Jurnal Pencemaran_Air.

Pratiwi, G. (2014). Deskripsi Kemampuan Pemecahan Masalah Siswa Pada Konsep 
Pencemaran Lingkungan Studi Deskriptif pada Siswa Kelas VII Semester Genap SMP Negeri 3 Pringsewu Bandar Lampung. Skripsi (UNILA)

Prihastuti, W. S., Hudiono, B., \& Mirza, A. (2013). Pemecahan masalah matematis siswa ditinjau dari tingkat kemampuan dasar matematika. Jurnal Pendidikan dan Pembelajaran, 2 (12), 116. http://jurnal.untan.ac.id/index.php/jpdpb/article /download/3997/4014.

Slameto. (2010). Belajar dan Faktor-faktor yang Mempengaruhinya. Rineka Cipta: Jakarta.

Slavin. (2012). Cooperative Learning; Teori, Riset dan Praktik, Penerjemah Nurulita Yusron. Nusa Media: Bandung.

Sugiyono. (2011). Metode Penelitian Kuantitatif Kualitatif dan $R \& D$. Alfabeta: Bandung.

Sujana, A. (2013). Pendidikan IPA Teori dan Praktik. Rizqi Press: Bandung.

Sukmadinata, N. S. (2013). Metode Penelitian Pendidikan. PT. Remaja Rosdakarya: Bandung.
Supardi. (2013). Aplikasi Statistika dalam Penelitian Konsep Statistika yang Lebih Komprehensif. Change Publication: Jakarta.

Syahrotun. S. (2016). Analisis Kemampuan Pemecahan Masalah Matematis Siswa Sekolah Menengah Pertama Di Kota Bandung. Bandung. Skripsi (UPI).

Trianto. (2010). Model Pembelajaran Terpadu Konsep, Strategi, dan Implementasinya dalam Kurikulum Tingkat Satuan Pendidikan (KTSP). PT Bumi Aksara: Jakarta.

Wahono, dkk. (2013). Materi Pencemaran air untuk smp/mts kelas VII. Erlangga: Jakarta.

Wena, M. (2010). Strategi Pembelajaran Inovatif Kontemporer. Bumi Aksara: Jakarta.

Widodo, W., \& Fida. (2016). Ilmu Pengetahuan Alam. Kementerian Pendidikan dan Kebudayaan Edisi Revisi. Kementerian Pendidikan dan Kebudayaan: Jakarta.

Widodo, A. (2010). Pendidikan IPA di Sekolah Dasar. UPI Press: Bandung. 